\title{
Iron metabolism during lactation in the rabbit
}

\author{
By H. TARVYDAS, SUSAN M. JORDAN AND E. H. MORGAN \\ Department of Physiology, The University of Western Australia, \\ Nedlands, Western Australia
}

(Received 16 October 1967-Accepted 29 April 1968)

\begin{abstract}
I. Iron metabolism was studied during lactation in the rabbit by the intravenous injection of ${ }^{59} \mathrm{Fe}$ in order to measure plasma $\mathrm{Fe}$ turnover, $\mathrm{Fe}$ transfer to the milk and Fe absorption by the suckling young.

2. Although the plasma and red cell volumes were elevated in the lactating animal a significant increase of plasma Fe turnover was not demonstrated.

3. Between 2.5 and $11 \cdot 5 \%$ of the injected dose of ${ }^{50} \mathrm{Fe}$ appeared in the milk during the following 2-3 weeks. Secretion into the milk continued for at least 2 weeks, and the specific activity of $\mathrm{Fe}$ was higher in milk than in plasma, suggesting that the mammary gland contained a pool of $\mathrm{Fe}$, with a low turnover rate from which milk $\mathrm{Fe}$ was derived. On the average, I $5^{\circ}-315 \mu \mathrm{g}$ Fe were secreted in the milk per day.

4. Almost all the ${ }^{59} \mathrm{Fe}$ ingested by suckling rabbits, either in milk or sodium chloride solution, was absorbed.

5. It is concluded that in the rabbit the relatively small increase of body Fe which occurs during suckling is entirely due to the limited supply of Fe available in the milk. The high concentration of Fe-binding protein present in rabbit milk did not appear to aid Fe transfer into the milk or to affect $\mathrm{Fe}$ absorption by the young.
\end{abstract}

The metabolism of iron during lactation in the rabbit is of interest for several reasons. Rabbit milk is extremely rich in an Fe-binding protein with properties similar to plasma transferrin (Jordan, Kaldor \& Morgan, 1967). The function of this protein is uncertain but it could play a part in the transfer of Fe from plasma to milk in the lactating animal or in intestinal $\mathrm{Fe}$ absorption by the suckling young. In addition the young rabbit is born with a high body $\mathrm{Fe}$ content when compared with other species, but shows relatively little increase in body Fe during. suckling (Bunge, 1892; Widdowson, 1950; McCance \& Widdowson, 1951). The reasons for this may be a low content of $\mathrm{Fe}$ in rabbit milk or poor efficiency of absorption of the Fe by the young, possibly as a consequence of the high concentration of Fe-binding protein in the milk. These problems were considered in the present investigation, which also provided information on the effects of lactation on the turnover rate of maternal plasma $\mathrm{Fe}$ and on erythropoiesis.

\section{EXPERIMENT A L}

Animals

The experiments were performed on lactating and non-lactating female hybrid rabbits. They were housed in individual metabolism cages. During the course of each day the lactating animals were separated from their litters except for a single short suckling period of about $5 \mathrm{~min}$ daily in the morning between 09.00 and $10.00 \mathrm{~h}$. It is the normal habit of rabbits to suckle their young only once a day (Deutsch, 1957; Zarrow, Denenberg \& Anderson, 1965). The rate of weight gain of young rabbits 
which are separated from their mothers except for a single suckling period daily is the same as for young which have free access to their mothers (Zarrow et al. I965; and personal observation).

\section{Experimental procedure}

Radioactive $\mathrm{Fe}$ in the form of $\left[{ }^{59} \mathrm{Fe}\right]$ ferric citrate was incubated with fresh rabbit plasma for $3^{\circ} \mathrm{min}$ at $37^{\circ}$ before administration to the rabbits. Care was taken not to exceed the latent Fe-binding capacity of the plasma transferrin. From $15^{-20} \mu \mathrm{c}$ of the plasma-bound ${ }^{59} \mathrm{Fe}$ was injected by a marginal ear vein into lactating and nonlactating rabbits. Injections were made into lactating rabbits in the morning just after they had been allowed to suckle their young. Blood samples were collected by incision of the marginal vein of the ear not injected. Milk samples were collected manually in the mornings before suckling, after the subcutaneous injection of $2 \cdot 5$ i.u. oxytocin.

Ferrokinetic measurements were made by collecting four blood samples during the Ist $\mathrm{h}$ after injecting the ${ }^{59} \mathrm{Fe}$ and a further sample was taken each day for the next 10 days. The plasma radioactivity of the first four samples was used for the measurement of plasma $\mathrm{Fe}$ turnover, and the whole-blood activity of the later samples for the determination of the incorporation of radioactive $\mathrm{Fe}$ into erythrocytes. The volume of milk secreted each day was measured by the sum of the volume expressed from the mammary glands and the difference in body-weight of the young before and after suckling, on the assumption that $\mathrm{I} \mathrm{ml}$ milk weighs $\mathrm{I} \mathrm{g}$. The amount of radioactive $\mathrm{Fe}$ secreted into the milk was determined by whole-body counting of the young before and after suckling and by measuring the ${ }^{59} \mathrm{Fe}$ in the expressed milk.

The intestinal absorption of $\mathrm{Fe}$ by the suckling young was measured in three ways. The first was by whole-body counting of the young daily for 8 days before and after suckling from mothers which had received radioactive $\mathrm{Fe}$. In the second method ${ }^{59} \mathrm{Fe}$ was injected into four rabbits which were allowed to suckle their young on the next two mornings. These young were then exchanged with litters of the same age from mothers which had not received radioactive $F e$ and the young were counted for whole-body radipactivity every I or 2 days for 14 days. The third measurement of $\mathrm{Fe}$ absorption was made on two litters each of four young which had been separated from their mothers overnight. Two young from each litter were given, through a polythene cannula passed into the stomach, $10 \mathrm{ml}$ milk freshly obtained from their own mothers; to this milk I $\mu \mathrm{c}^{59} \mathrm{Fe}$ as ferric citrate had been added and the mixture had been incubated at $37^{\circ}$ for $30 \mathrm{~min}$ before administration to the young. The other two young of each litter were given $45 \mu \mathrm{g} \mathrm{Fe}$ as ferrous ammonium sulphate labelled with $\mathrm{I} \mu \mathrm{c}$ ${ }^{59} \mathrm{Fe}$ in $10 \mathrm{ml} 0.9 \%(\mathrm{w} / \mathrm{v})$ sodium chloride solution. The whole-body radioactivity of the young was measured immediately after giving the radioactive $\mathrm{Fe}, 4 \mathrm{~h}$ later, the next day, and then every 2 nd day for 2 weeks.

\section{Analytical methods}

Haemoglobin was determined by the oxyhaemoglobin method and haematocrit by the microhaematocrit technique. Fe concentrations in plasma and milk were measured by the methods of Morgan \& Carter (1959) and Ezekiel (1965) respectively. 
The radioactivity of plasma, whole blood and milk samples was measured in a welltype scintillation counter. Whole-body radioactivity was determined in a smallanimal whole-body counter (Warner \& Oliver, I962). Corrections for radioactive decay and for the increasing size of the growing suckling rabbits were made by counting standards prepared from the administered ${ }^{59} \mathrm{Fe}$-containing solutions diluted to the volumes of the samples being counted. Plasma volume was determined from the administered dose of radioactive $\mathrm{Fe}$ and from the concentration of radioactive $\mathrm{Fe}$ in the plasma obtained by extrapolation of the plasma radioactivity values to zero time. Plasma Fe turnover was calculated from the plasma volume, plasma Fe concentration and plasma radioactivity values as described by Bothwell \& Finch (I962). The fraction of injected ${ }^{59} \mathrm{Fe}$ incorporated into erythrocytes was calculated from the plasma volume, haematocrit, whole-blood radioactivity and the whole body:peripheral haematocrit ratio of 0.92 ; this ratio was determined in six non-lactating rabbits by means of ${ }^{59} \mathrm{Fe}-$-labelled erythrocytes and ${ }^{131}$ I-labelled rabbit albumin.

\section{RESULTS}

The haematological and ferrokinetic values for six rabbits on the 2 nd day and for four on the I $4^{\text {th }}$ day of lactation and for six non-lactating animals are summarized in Table $\mathrm{I}$. The mean haemoglobin and haematocrit values for the lactating animals did not differ significantly from those for the non-lactating animals, but the plasma and

Table I. Mean values with their standard errors for haematological and ferrokinetic measurements of lactating and female non-lactating rabbits

\begin{tabular}{|c|c|c|c|}
\hline \multirow[b]{2}{*}{ No, of rabbits ... } & \multicolumn{2}{|c|}{ Lactating } & \multirow[b]{2}{*}{$\begin{array}{c}\text { Non-lactating } \\
6\end{array}$} \\
\hline & $\begin{array}{c}\text { Day } 2 \\
6\end{array}$ & $\begin{array}{r}\text { Day } 14 \\
4\end{array}$ & \\
\hline Body-weight (kg) & $3.21 \pm 0.25$ & $2 \cdot 90 \pm 0.31$ & $3 \cdot 24 \pm 0 \cdot 25$ \\
\hline Blood haemoglobin $(\mathrm{g} / \mathrm{roo} \mathrm{ml})$ & $10.7 \pm 0.39$ & $\mathrm{II} \cdot 0 \pm 0.47$ & $10.2 \pm 0.39$ \\
\hline Haematocrit $(\%)$ & $3 I \cdot 5 \pm I \cdot I$ & $33 \cdot 2 \pm 1 \cdot 4$ & $32 \cdot 8 \pm I \cdot I$ \\
\hline Plasma volume ( $\mathrm{ml} / \mathrm{kg}$ body-wt) & $36 \cdot 5 \pm I \cdot 8$ & $43 \cdot 7 \pm 2 \cdot 3$ & $32 \cdot 0 \pm 1 \cdot 8$ \\
\hline Plasma Fe content $(\mu \mathrm{g} / \mathrm{ml})$ & $2.44 \pm 0.24$ & $2 \cdot 52 \pm 0.30$ & $\mathrm{I} \cdot 65 \pm 0.24$ \\
\hline $\begin{array}{l}\text { Plasma Fe turnover (mg/kg body-wt } \\
\text { day) }\end{array}$ & $1.01 \pm 0.22$ & $I \cdot 45 \pm 0 \cdot 27$ & $0.90 \pm 0.22$ \\
\hline $\begin{array}{l}\text { Incorporation of }{ }^{59} \mathrm{Fe} \text { into } \\
\text { crythrocytes }(\%)\end{array}$ & $70 \cdot 3 \pm 6 \cdot 1$ & $84 \cdot 1 \pm 7 \cdot 5$ & $82 \cdot 6 \pm 6 \cdot 1$ \\
\hline $\begin{array}{l}\text { Red blood cell volume } \\
(\mathrm{ml} / \mathrm{kg} \text { body-wt })\end{array}$ & $15 \cdot 4 \pm I \cdot 2$ & $20 \cdot 0 \pm 1 \cdot 5$ & $14 \cdot 4 \pm 1 \cdot 2$ \\
\hline
\end{tabular}

red blood cell volumes were significantly $(P<0.05)$ greater on the 14 th day of lactation than on the 2 nd day of lactation, or in the non-lactating animals. The mean plasma $\mathrm{Fe}$ concentration was significantly higher on the and day of lactation $(P<0.05)$ than in the non-lactating animals. There was no significant difference between the three groups in the mean values for plasma $\mathrm{Fe}$ turnover or the fraction of injected radioactive $\mathrm{Fe}$ incorporated into erythrocytes $(P>0.05)$.

The transfer of injected radioactive $\mathrm{Fe}$ into the milk, as measured by whole-body counting of the young rabbits, was studied for $12-2 \mathrm{I}$ days in five rabbits: three injected 
with ${ }^{59} \mathrm{Fe}$ on the 2 nd day of lactation and two on the $\mathrm{r} 4 \mathrm{th}$ day. The cumulative secretion of the ${ }^{59} \mathrm{Fe}$ is shown in Fig. I. Between $2 \cdot 7 \%$ and $\mathrm{II}^{\circ} \cdot 4 \%$ of the injected radioactive $\mathrm{Fe}$ was secreted into the milk during the period of observation. The rate of secretion of the ${ }^{59} \mathrm{Fe}$ was maximal during the first few days after injection and progressively slowed down thereafter, but significant amounts continued to be secreted each day for approximately 2 weeks. One of the rabbits injected on the 2nd day of lactation showed a much lower rate of appearance of the radioactive $\mathrm{Fe}$ in the milk than the other two injected on the and day (Fig. I). This rabbit had a very high rate of plasma

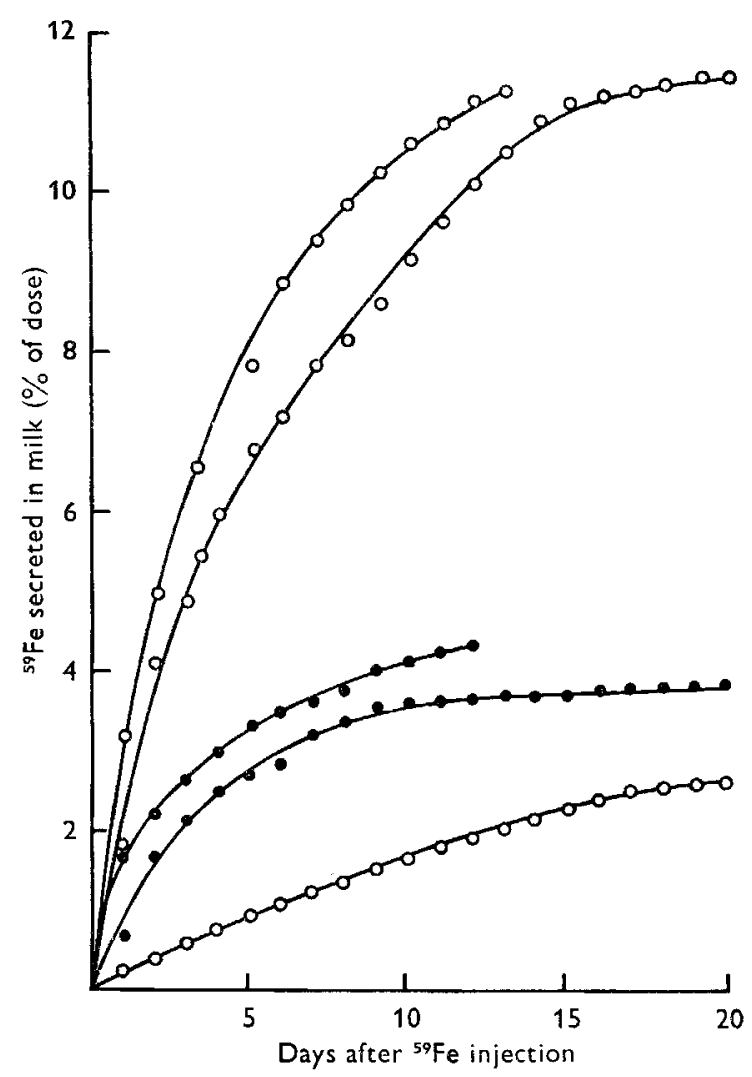

Fig. I. Cumulative secretion of ${ }^{59} \mathrm{Fe}$ in the milk of rabbits after intravenous injection on the 2 nd $(O)$ or I 4 th $(\bullet)$ day of lactation.

$\mathrm{Fe}$ turnover (2.1 $\mathrm{mg} / \mathrm{kg}$ per day) and $97 \%$ of the injected radioactive $\mathrm{Fe}$ was incorporated into the red blood cells. Its blood haemoglobin concentration was $10 \cdot 2$ $\mathrm{g} / \mathrm{roO} \mathrm{ml}$. and plasma Fe concentration $190 \mu \mathrm{g} / \mathrm{ro0} \mathrm{ml}$.

Measurements were made of $\mathrm{Fe}$ concentration and ${ }^{59} \mathrm{Fe}$ in plasma and milk during the first 3 days after injection of ${ }^{59} \mathrm{Fe}$ into four rabbits on the 2nd day of lactation and into four on the $14^{\text {th }}$ day of lactation (Table 2 ). The concentration of Fe was significantly higher in milk than in serum on the $3^{\text {rd }}-5^{\text {th }}$ days of lactation $(P<0.05)$, but milk and serum values were very similar in the rabbits injected on the $14^{\text {th }}$ day of 
lactation. There was no evidence of a relationship between serum and milk Fe concentrations in individual rabbits. Plasma radioactivity was very low by the morning after the injections, and the specific activity of Fe was much higher in the milk than in the plasma. The total amount of Fe secreted into the milk was calculated from the Fe concentration of the milk and volumes of milk secreted. The mean values varied from approximately I 50 to $300 \mu \mathrm{g} \mathrm{Fe}$ per day both in early and in middle lactation.

Table 2. Serum and milk iron concentration, ratio of milk specific activity:serum specific activity, and daily total amount of Fe secreted into milk for 3 days after intravenous injection of ${ }^{59} \mathrm{Fe}$ into four rabbits on the 2 nd day and four on the I4th day of lactation

\begin{tabular}{|c|c|c|c|c|c|c|c|c|}
\hline \multirow[b]{2}{*}{ Day of lactation } & \multirow[b]{2}{*}{3} & \multirow[b]{2}{*}{4} & \multirow[b]{2}{*}{5} & \multirow[b]{2}{*}{15} & \multirow[b]{2}{*}{16} & \multirow[b]{2}{*}{17} & \multicolumn{2}{|c|}{ Standard error } \\
\hline & & & & & & & $A^{*}$ & $\mathbf{B} \dagger$ \\
\hline $\begin{array}{l}\text { Plasma Fe concentration } \\
(\mu \mathrm{g} / \mathrm{ml})\end{array}$ & $2 \cdot 3$ & $2 \cdot I$ & $\mathrm{I} \cdot 5$ & $2 \cdot 4$ & $2 \cdot 3$ & $2 \cdot I$ & \pm 0.25 & \pm 0.10 \\
\hline Milk Fe concentration $(\mu \mathrm{g} / \mathrm{ml})$ & $3 \cdot 9$ & $4 \cdot 6$ & $3 \cdot 8$ & $2 \cdot 4$ & $2 \cdot 7$ & $2 \cdot 3$ & \pm 0.58 & \pm 0.26 \\
\hline $\begin{array}{l}\text { Ratio, milk: serum Fe } \\
\text { specific activity }\end{array}$ & $2 \cdot 5$ & $12 \cdot 4$ & 13.7 & $2 \cdot 8$ & $2 I \cdot 2$ & $23 \cdot 2$ & $\pm I \cdot 7$ & $\pm 2 \cdot 5$ \\
\hline $\begin{array}{l}\text { Milk Fe content } \\
(\mu \mathrm{g} \text { secreted/day })\end{array}$ & 152 & 176 & 300 & 259 & 222 & 315 & \pm 53 & \pm 24 \\
\hline
\end{tabular}

* Standard error for effect of stage of lactation at which rabbits were injected.

+ Standard error for effect of time after injection.

Table 3. Whole-body radioactivity of suckling rabbits on days $\mathbf{1}-7$ after intravenous injection of their mothers with ${ }^{59} \mathrm{Fe}$

\begin{abstract}
(Results are given as the ratio of the whole-body count immediately before each feeding to that after the previous day's feeding, expressed as percentages. Standard error of the means, \pm 0.30 )
\end{abstract}

\begin{tabular}{|c|c|c|c|c|c|c|c|c|}
\hline $\begin{array}{c}\text { Day of } \\
\text { lactation }\end{array}$ & & & & le bod & lioactiv & o) on & & \\
\hline${ }^{59} \mathrm{Fe}$ injected & sucklings & $\mathbf{I}$ & 2 & 3 & 4 & 5 & 6 & 7 \\
\hline 2 & 15 & $98 \cdot 9$ & $96 \cdot 5$ & $100 \cdot 0$ & $100 \cdot 3$ & 99.5 & $99 \div 7$ & $99 \cdot 3$ \\
\hline 14 & 10 & 99.7 & IOI' 3 & 1000 & $99 \cdot 3$ & $99^{\circ} 0$ & $98 \cdot 8$ & $99 \cdot I$ \\
\hline
\end{tabular}

Whole-body counts on fifteen young of three litters in early lactation and on ten young of two litters in middle lactation were made after each time of suckling and again on the following morning before the next suckling period; in no instance was there a significant loss of radioactivity between the two measurements, even though they were studied in this way for 7 days (Table 3 ). Confirmation of this high efficiency of Fe absorption was obtained with the four litters allowed to suckle rabbits secreting ${ }^{59} \mathrm{Fe}$ in their milk for 2 days, and then fostered to rabbits which had received no radioactive Fe. Two litters (nine young) received the ${ }^{59} \mathrm{Fe}$ on the $3^{\text {rd }}$ and 4 th days of lactation and two litters (fifteen young) received it on the 18 th and 19 th days of lactation. In all the young the amount of radioactive Fe retained 8 days after the second feed containing ${ }^{59} \mathrm{Fe}$ was $93-103 \%$ of the amount ingested and $\mathrm{I} 4$ days after the and feed it was $9 \mathrm{I}-\mathrm{IO} 2 \%$ (Table 4 ). 
When radioactive $\mathrm{Fe}$ was given to 4-day-old rabbits by stomach tube and daily whole-body counting of the young was continued for $\mathrm{I}_{4}$ days it was again found that the radioactive $F e$ was almost completely retained. No difference was observed between the retention of $\mathrm{Fe}$ by the young which received $\mathrm{Fe}$ administered with milk and those in which it was given in physiological saline (Table 5).

Table 4. Whole-body radioactivity, on days 8 and $\mathrm{I}_{4}$ after ingesting ${ }^{59} \mathrm{Fe}$, of young rabbits which suckled for 2 days from rabbits injected intravenously with ${ }^{59} \mathrm{Fe}$ and then from rabbits which had received no ${ }^{59} \mathrm{Fe}$

(Results are expressed as a percentage of the whole-body radioactivity determined inmediately after the second ${ }^{59} \mathrm{Fe}$-containing feed. Standard error of the means, $\pm 0.6 \mathrm{r}$ )

$$
\begin{aligned}
& \text { Days of lactation } \\
& \text { when }{ }^{59} \mathrm{Fe} \text { fed } \\
& 3 \text { and } 4 \\
& 18 \text { and } 19
\end{aligned}
$$

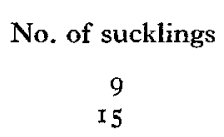

$\begin{array}{cc}\text { Whole-body radioactivity }(\%) \\ \text { Day } 8 & \text { Day 14 } \\ 96 \cdot 7 & 94 \cdot 8 \\ 98 \cdot 4 & 96.3\end{array}$

Table 5. Whole-body radioactivity of rabbits on days I, 8 and $\mathrm{I} 4$ after administration of ${ }^{59} \mathrm{Fe}$ given intragastrically on the 4 th day of life

(Results are expressed as percentages of the whole-body radioactivity immediately after administration of the ${ }^{59} \mathrm{Fe}$. Standard error of the means, \pm 0.47 )

\author{
${ }^{59} \mathrm{Fe}$ solution \\ Rabbit milk \\ Saline
}

Whole-body radioactivity (\%) on day:

$\begin{array}{ccc}\text { I } & 8 & \text { I4 } \\ 99 \cdot 5 & 99 \cdot 2 & 99 \cdot 7 \\ 98 \cdot 2 & 99 \cdot 0 & 98 \cdot 0\end{array}$

\section{DISCUSSION}

The mean plasma and red cell volumes of the rabbits examined on the I4th day of lactation were greater than the values for the rabbits on the 2nd day of lactation and for the non-lactating animals. An increase of plasma and blood volumes during lactation has also been reported for the rat (Bond, 1958 ). The increase in red cell volume between the 2 nd and 14 th days of lactation must be attributed to an increase of erythropoiesis from the low level found in late pregnancy in the rabbit (Bothwell, Pribilla, Mebust \& Finch, 1958), to values above those found in non-lactating rabbits. This would be expected to cause an increase in the rate of turnover of plasma Fe. The mean amounts of $\mathrm{Fe}$ secreted in the milk on the $3^{\text {rd }}$ and ${ }_{1} 5_{\text {th }}$ days of lactation (Table 2) were approximately $5 \%$ of the mean values for the turnover rate of plasma Fe determined on the previous days (Table I). Hence there might also be a small additional increase in the turnover rate of plasma $\mathrm{Fe}$ to account for $\mathrm{Fe}$ transfer to the milk. However, probably as a result of the degree of variation between animals, the mean values for the rate of turnover of plasma $F e$ in the lactating rabbits were not significantly greater than those for non-lactating ones.

The continued secretion of radioactive Fe into the milk for $\mathbf{1} 2$ or more days after a single intravenous injection, and the much greater specific activity of $\mathrm{Fe}$ in milk than 
in plasma $\mathrm{I}-3$ days after the injection, suggests that most of the radioactive $\mathrm{Fe}$ must enter the mammary glands soon after the injection and be stored there for up to several days before it is secreted. The rate of appearance of ${ }^{59} \mathrm{Fe}$ in the milk in four of the five rabbits represented in Fig. I approximates very closely to single exponentials with slopes of $0.17-0.3^{\circ}$ per day during the first 7 days after its administration. If it is assumed that all the radioactive $\mathrm{Fe}$ secreted in the milk in these four animals was taken up by the mammary gland within $24 \mathrm{~h}$ of its administration and that it mixed freely with the Fe pool in the mammary gland, from which the milk Fe was derived, it can be calculated from the radioactivity of the milk and total Fe values that the size of this pool varied from 0.6 to $\mathrm{I} \cdot 75 \mathrm{mg}$. The chemical nature of this pool is uncertain. Ferritin has been implicated in the transfer of $\mathrm{Fe}$ through the intestinal mucosa and the placenta (Heilmeyer, 1958) although the part played by ferritin in these processes is by no means clear. Possibly in the rabbit the Fe pool in the mammary gland is in the form of ferritin. This is suggested by the slow rate of turnover, but chemical investigations are required before any definite conclusions can be reached.

The reason for the low rate of secretion of radioactive Fe into the milk in one of the rabbits injected on the second day of lactation (Fig. I) is probably that the rate of erythropoiesis was very high in this animal at the time of injection and that the erythropoietic tissue competes with the mammary gland for plasma $\mathrm{Fe}$. The high rate of erythropoiesis is shown by the values for plasma Fe turnover (2. I mg/kg per day) and the percentage incorporation of radioactive $\mathrm{Fe}$ into red blood cells $(97 \%)$ which were considerably greater than the mean values for rabbits at this stage of lactation (Table $\mathrm{I}$ ). Possibly this rabbit was recovering from an abnormally large fall in haemoglobin level during pregnancy or an excessive blood loss at the time of parturition, although its blood haemoglobin concentration and plasma Fe concentration were not very low at the time of examination.

Iron secretion into milk in the rabbit contrasts strongly with that in the rat where intravenous radioactive $\mathrm{Fe}$ is very rapidly transferred to the milk after mixing with a very small pool in the mammary gland (I. Kaldor, personal communication). The rat, too, achieves a much greater concentration of $\mathrm{Fe}$ in its milk than does the rabbit (Kaldor \& Ezekiel, I962; Ezekiel \& Morgan, 1963). The little information available for the cow (Erf, r94I) indicates that in this species, also, radioactive Fe is largely transferred to the milk within $\mathbf{r}-\mathbf{2}$ days after intravenous injection, but here the $\mathrm{Fe}$ concentration of the milk is very low (Underwood, I962).

It has been postulated that Fe transfer from plasma to milk is regulated by the mammary gland content of Fe-binding protein (Blanc \& Isliker, I963). The milk protein was thought to compete for the Fc of plasma transferrin. The present results in the rabbit are strongly opposed to this view. Direct transfer from plasma to the Fe-binding proteins of milk would be expected to occur rapidly and to involve only a small mammary gland $\mathrm{Fe}$ pool. In addition, the extremely high Fe-binding capacity of rabbit milk (Jordan et al. I 967 ) should result in large transfer of Fe from plasma to milk, but this is not so when the rabbit is compared with the rat and the quokka (Setonix brachyurus) which have milk much richer in Fe but with much lower Fe- 
binding capacities (Kaldor \& Ezekiel, 1962; Ezekiel, I965; Jordan \& Morgan, unpublished).

The almost complete absorption and retention of ingested radioactive $\mathrm{Fe}$ by suckling rabbits is remarkable. Similar high values have also been reported for the suckling rat (Ezekiel, 1967), but are not observed in suckling infants (Schulz \& Smith, I958; Garby \& Sjölin, 1959) or in adult animals even in the presence of severe Fe deficiency and anaemia (Bothwell \& Finch, 1962). It is thought that the efficiency of $\mathrm{Fe}$ absorption in adult animals is largely determined by the $\mathrm{Fe}$ content of intestinal mucosal cells (Wheby, 1966). This is governed by both the Fe content of the diet and the amount of $\mathrm{Fe}$ which the mucosal cells can obtain from the plasma in competition with the other tissues of the body, especially the bone marrow. Possibly the Fe content of the intestinal mucosa of the suckling rabbit and rat is very low, so that there is no storage $\mathrm{Fe}$ pool which can trap absorbed $\mathrm{Fe}$, and as a result it is all transferred to the plasma. Furthermore the efficiency of Fe uptake by the mucosal cells from the intestinal lumen must be almost $100 \%$. In the rat the efficiency of Fe absorption starts to decline after the I4th day of life (Ezekiel, I967). This may be associated with the taking of solid food and an increase in both the amount of $\mathrm{Fe}$ ingested and the Fe content of mucosal cells, or it may be due to maturation of mucosal cells as is shown by the cessation of immunoglobulin absorption at about the 18 th day (Halliday, 1956). In the present work no decrease in $\mathrm{Fe}$ absorption was found up to the age of the oldest rabbits studied (I9 days). More work is required to determine at what age $\mathrm{Fe}$ absorption begins to decline and to elucidate the mechanisms of Fe absorption in suckling rabbits and rats. This may well provide very useful information as to the processes controlling $\mathrm{Fe}$ absorption at older ages. It may be noted that the suckling rabbit, unlike the rat, is unable to absorb immunoglobulins from the intestine (Brambell, 1958).

The results for $\mathrm{Fe}$ absorption show that the high Fe-binding protein content of rabbit milk does not impair absorption of Fe by the young. Probably it was also not responsible for the very great efficiency of absorption observed. The young given ${ }^{59} \mathrm{Fe}$ in saline had not eaten for $24 \mathrm{~h}$ so it is unlikely that Fe-binding protein remained in their stomachs or upper intestines at the time of testing. Nevertheless they absorbed the radioactive $\mathrm{Fe}$ just as efficiently as when it was given in milk.

Since essentially all of the $\mathrm{Fe}$ in milk was absorbed by the young, the amount of $\mathrm{Fe}$ absorbed daily can be calculated from milk volume and Fe concentration. No measurements of faecal $\mathrm{Fe}$ or whole-body Fe were made in the present work, but the almost complete retention of orally administered radioactive Fe for at least 2 weeks (Tables 4, 5) indicates that $\mathrm{Fe}$ excretion is as low in suckling rabbits as in older animals, and therefore the body $\mathrm{Fe}$ content should increase by the amount absorbed. The average amount of $\mathrm{Fe}$ secreted per day was approximately $240 \mu \mathrm{g}$, or $40 \mu \mathrm{g}$ per suckling for a litter of six, and this amount remained relatively constant for at least the first 2.5 weeks of lactation. Hence the average suckling would be expected to show an increase of body $\mathrm{Fe}$ of about $0.56 \mathrm{mg}$ between the $2 \mathrm{nd}$ and I 6 th days of life. Such an increase is only a little more than the increase of $0.44 \mathrm{mg}$ found by chemical analysis of suckling rabbits aged $O$ and ${ }_{5} 5$ days by McCance \& Widdowson (I95). This rela- 
tively small increase of total body Fe during suckling in the rabbit compared with that in other animals may be entirely attributed to the limited supply of $\mathrm{Fe}$ in the milk ingested by young rabbits. Fortunately because of the very large Fe reserves of the newborn rabbit it is able to withstand a low Fe intake during the suckling period without suffering from severe Fe deficiency.

This work was supported by a grant from the National Health and Medical Research Council of Australia. Mr H. Tarvydas was the recipient of a Vacation Scholarship of the National Heart Foundation of Australia. The writers are indebted to $\mathrm{Mr} \mathrm{T}$. T. Loh for performing the measurements of iron concentration in milk and to $\mathrm{Mr} \mathrm{N}$. Stenhouse for performing the statistical analyses.

\section{REFERENCES}

Blanc, B. \& Isliker, H. (1963), Helv. physiol. pharmac. Acta 21, 259.

Bond, C. F. (1958.) Endocrinology 63, 285.

Bothwell, T. H. \& Finch, C. A. (1962). Iron Metabolism. London: J. and A. Churchill Ltd.

Bothwell, T. H., Pribilla, W. F., Mebust, W. \& Finch, C. A. (1958). Am. F. Physiol. 193, 6r 5.

Brambell, F. W. R. (1958). Biol. Rev. 33, 488

Bunge, G. (1 892). Hoppe-Seyler's Z. physiol. Chem. 16, 173.

Deutsch, J. Z. (1957). Br. F. Anim. Behav. 5, 53.

Erf. L. A. (194I). Proc. Soc. exp. Biol. Med. 46, 284.

Ezekiel, E. (1965). Biochim. biophys. Acta ro7, 5 I I.

Ezekiel, E. (1967). F. Lab. clin. Med. 70, 138 .

Ezekiel, E. \& Morgan, E. H. (1963). F. Physiol., Lond. 165, 336.

Garby, L. \& Sjölin, S. (I959). Acta Paediat. 48, (Suppl. I I 7), p. 24

Halliday, R. (1956). Proc. R. Soc. B, 145, 179.

Heilmeyer, L. (1958). In Iron in Clinical Medicine, p. 24. [R. O. Wallerstein and S. R. Mettier, editors.] London: Cambridge University Press.

Jordan, S. M., Kaldor, I. \& Morgan, E. H. (1967). Nature, Lond. 215, 76.

Kaldor, I. \& Ezekiel, E. (1962). Nature, Lond. 196, 175.

McCance, R. A. \& Widdowson, E. M. (r95I). F. Physiol., Lond. rr2, 450.

Morgan, E. H. \& Carter, G. (1959). Australas. Ann. Med. 9, 209.

Schulz, J. \& Smith, N. J. (1958). Am. F. Dis. Child. 95, ro9.

Underwood, E. J. (1962). Trace Elements in Human and Animal Nutrition, and ed., p. 22. New York: Academic Press Inc.

Warner, G. T. \& Oliver, R. (1962). Br. F. Radiol. 35, 349.

Wheby, M. S. (1966). Gastroenterology 50, 888 .

Widdowson, E. M. (1950). Nature, Lond. 166, 626.

Zarrow, M. X., Denenberg, V. H. \& Anderson, C. O. (1965). Science, N.Y. 150, I835. 